\title{
POLÍTICAS PÚBLICAS E AGÊNCIAS REGULADORAS
}

\author{
Augusto Martinez Perez Filho*
}

\begin{abstract}
Sumário: Introdução-1. Aspolíticas públicasnoâmbitodaAdministração-2. As agências reguladoras: conceito, origens e atribuições no direito brasileiro-3. Políticas públicase o papel das agências reguladoras - 4 . A gestão democrática das agências na realização de políticas públicas: a participação popular e o papel do consumidor - 5 . Conclusão
\end{abstract}

- Resumo: O presente estudo traça linhas aproximativas entre a temática das políticas públicas com a ciência do direito. A sociedade brasileira clama pela concretização de políticas públicas hábeis a lançar nosso país à condição inquestionável de país desenvolvido. As agências reguladoras desempenham relevante papel na economia e podem influenciar na implementação e efetivação de políticas públicas, na medida em que estabelecem a regulação de monopólios, estabelecem regras relacionadas à concorrência no mercado e também realizam a chamada "regulação social", onde o objetivo primordial não é econômico, mas possibilitar a prestação de serviços de maneira universal e com respeito ao meio-ambiente. Neste contexto, as agências reguladoras podem e devem auxiliar no atingimento desta meta por meio de uma atuação proativa no âmbito de suas competências.

- Palavras-chave: direito; políticas públicas; agências reguladoras.

- Abstract: This study provides approximate lines between the themes of public policy with the science of law. Brazilian society calls for the implementation of public policies able to launch our country to be unquestionable developed country. Regulatory agencies have a crucial role in the economy and can influence the implementation and execution of public policy, insofar as they establish the regulation of monopolies, establish rules related to market competition and also perform so-called "social regulation", where the primary goal is not economical, but enable the provision of a universal manner with respect to the environment. In this context, the regulatory agencies can and should assist in achieving this goal through a proactive role within their competence.

- Keywords: law; public policies; regulatory agencies.

\section{Introdução}

A lição clássica de Seabra Fagundes no sentido de que "administrar é aplicar a lei de ofício" ${ }^{11}$ deve ser compreendida sob a ótica da concretização dos direitos postos nos textos legais, sobretudo na Constituição Federal.

Política pública, por sua vez, representa "instrumento que orienta a ação estatal"2, ou seja, ela é que deve pautar a correta aplicação da lei, de tal modo que o administrador, no desempenho de sua competência, exare atos administrativos que traduzam esse propósito, não sob a ótica positivista da lei pela lei, mas no sentido de se buscar, por meio

\footnotetext{
*Masters in Law LL.M.- Brigham Young University e Mestrando em Direito - UNESP. Advogado. augustoperezfilho@gmail.com)

${ }^{1}$ FAGUNDES, Miguel Seabra, Controle dos atos administrativos pelo Poder Judiciário. 5. ed. Rio de Janeiro: Forense, 1979, p. 45.

${ }^{2}$ VALLE, Vanice Regina Lírio do. Políticas públicas, direitos fundamentais e controle judicial. Belo Horizonte: Fórum, 2009, p. 69.
} 
da ação administrativa, a concretização do direito posto no texto legal.

Ocorre que, não obstante seja tópico presente nas discussões de outras áreas do conhecimento, tais como a sociologia, ciência política e economia, o encontro de políticas públicas com a ciência do direito ainda é verificado com certa raridade. Leciona Vanice Regina Lírio do Valle que:

\begin{abstract}
"a matéria [políticas públicas] não se compadece com o timimg próprio do debate acadêmico, ou da sedimentação de uma teoria mais ampla e desenvolvida. (...) fato é que direito à saúde, educação, atendimento pré-escolar, dignidade em estabelecimentos prisionais, todos esses são temas que, por sua direta relação para com a preservação da dignidade da pessoa humana não admitem uma espécie de suspensão, até que a reflexão acadêmica se complete (...) num exercício dialógico de construção de uma matriz de raciocínio que é nova, ao menos, para a ciência do direito." 3
\end{abstract}

De outro giro, existe um embate histórico acerca do papel, necessidade e escopo da função do Estado, conforme lição de Antônio Luiz Machado Neto: "A temática das funções do Estado viveu, por séculos, enredada no problema axiológico de sua justificação."4

Diversos foram os conceitos e teorias desenvolvidas para explicar a razão de ser do Estado e suas funções. ${ }^{5}$ No caso brasileiro, a Constituição de 1988 decretou em seu artigo $1^{\circ}$ ser um Estado Democrático de Direito, ${ }^{6}$ cujo objetivo seria transformar o status quo 7 e construir, na lição de José Afonso da Silva, "um processo de convivência social numa sociedade livre, justa e solidária. ${ }^{8}$

A solidariedade social, preconizada por José Afonso da Silva e prevista ipsis litteris no texto da Magna Carta, hodiernamente se manifesta por meio de um Estado preocupado em dar respostas concretas às expectativas previstas pelo legislador, de modo a possibilitar o "convívio de múltiplos"9.

Natural, portanto, que a administração pública, e particularmente a

\footnotetext{
${ }^{3}$ Op. Cit. p. 72. (acrescentado).

${ }^{4}$ MACHADO NETO, Antônio Luís; Sociologia Jurídica. 6. ed.. São Paulo: Saraiva, 1987, p. 301.

${ }^{5}$ Para Antônio Luis Machado Neto, as teorias que propõem uma justificativa para o Estado são: a teológica, a jusnaturalista, a contratualista, a romântica, a hegeliana, a utilitária e a culturalista, de Gustav Radbruch. Em posição diametralmente oposta, a teoria anarquista busca negar qualquer justificativa ao Estado e propõe a sua extinção (op.cit. pp.301-302).

${ }^{6}$ CF- art.10: "A República Federativa do Brasil, formada pela união indissolúvel dos Estados e Municípios e do Distrito Federal, constitui-se em Estado Democrático de Direito..."

7 "A configuração do Estado Democrático de Direito não significa apenas unir formalmente os conceitos de Estado Democrático e Estado de Direito. Consiste, na verdade, na criação de um conceito novo, que leva em conta os conceitos dos elementos componentes, mas os supera na medida em que incorpora um componente revolucionário de transformação do status quo." (SILVA, José Afonso da. Curso de Direito Constitucional Positivo. 9. ed. São Paulo: Malheiros, 1993, p. 108).

${ }^{8}$ Op.cit. p. 109.

${ }^{9}$ VALLE, Vanice Regina Lírio do. Políticas públicas, direitos fundamentais e controle judicial. Belo Horizonte: Fórum, 2009, p. 22.
} 
administração pública indireta, na qual se incluem as agências reguladoras, no desempenho de suas atribuições, esteja em fiel consonância com os critérios de uma boa política pública.

\title{
1. As políticas públicas no âmbito da Administração
}

Edmir Netto de Araújo ensina que Administração Pública "é o conjunto de órgãos ou entidades (com seus servidores ou empregados) instituídos para a realização dos objetivos do Governo." ${ }^{10}$

Por sua vez, os objetivos de governo são materializados por meio das políticas públicas. Neste sentido, manifesta-se Floriano de Azevedo Marques Neto:

\begin{abstract}
“... políticas públicas são metas, programas, princípios e objetivos da ação governamental definidas a partir dos processos decisórios politicamente mediados com vistas a orientar, articular e coordenar a atuação de agentes públicos e privados e a alocação de recursos públicos e privados para atingir interesses públicos considerados relevantes..."11.
\end{abstract}

Em outras palavras, as políticas públicas representam programas e ações desenvolvidas pelo administrador público que, lançando mão do arcabouço jurídicoinstrumental à sua disposição, busca desenvolver projetos e adotar medidas que visem ao atendimento das necessidades dos administrados.

Ocorre que nem sempre a Administração Pública tem a agilidade que se espera no atendimento das necessidades básicas dos administrados, mormente em relação a direitos de primeira necessidade, aqueles que consubstanciam uma vida digna. ${ }^{12}$

A realidade brasileira está distante daquela nação idealizada no texto constitucional de 1988. Tome-se, por exemplo, a garantia constitucional inscrita no artigo 196, no sentido de que a "saúde é um direito de todos e um dever do Estado", cuja efetivação há de ser buscada "mediante políticas sociais e econômicas que visem à redução do risco de doença e de outros agravos e ao acesso universal e igualitário às ações e serviços para sua promoção, proteção e recuperação".

A ausência dessas políticas públicas eficientes, como posto no comando fundamental, na lição de João Gandini, Samantha Barioni e André Souza:

“...fica ofuscada - para não dizer satirizada - diante da tenebrosa realidade vivenciada nos milhares de hospitais e postos de saúde de todo o país. Faltam médicos, enfermeiros, medicamen-

\footnotetext{
${ }^{10}$ ARAÚJJ, Edmir Netto de. Curso de Direito Administrativo. 4. ed. São Paulo: Saraiva, 2009, p. 127. ${ }^{11}$ MARQUESNETO, Floniano de Azevedo. Agênciasreguladorasindependentes: fundamentose seuregimejurídico. 1.ed. 1. reimpressão. Belo Horizonte: Fórum, 2009, p. 86.

${ }^{12}$ Tais direitos traduzem as idéias de: "...educação, saúde, trabalho, moradia, lazer, segurança, previdência social, proteção à maternidade e à infância e assistência aos desamparados." (GANDINI, João A. D., BARIONE, Samantha F., SOUZA, André Evangelista de. A efetivação dos direitos sociais à saúde e à moradia por meio da atividade conciliadora do poder judiciário. In: SANTOS, Lenir (Org.). Direito da saúde no Brasil. Campinas: Saberes, 2010, p. 66).
} 


\begin{abstract}
tos, equipamentos, leitos. Sobram doentes espalhados pelos corredores, mães parindo em frente aos hospitais, recém-nascidos morrendo em decorrência de infecção hospitalar. A situação, cada vez mais dramática, exige urgente reestruturação, que deverá ocorrer, senão pelo bom senso dos administradores, por meio do cumprimento coercitivo das decisões do Poder Judiciário." 13
\end{abstract}

É o fenômeno da "judicialização" das políticas públicas, tão presente no cotidiano dos Tribunais pátrios, e que tem por origem a omissão do administrador. Esta injunção de um dos ramos de Poder na seara de outro, tem a ver com a leitura atualizada da carta magna, pois:

\begin{abstract}
"A Constituição Federal, sem nenhuma dúvida, assinalou o caráter substancial dos direitos decorrentes do princípio da dignidade da pessoa humana. Em virtude disso, qualquer interpretação que resulte na singela afirmação do caráter formal do instituto é violadora do espírito constitucional e usurpadora do inalienável direito que dela deriva." ${ }^{14}$
\end{abstract}

A dicção constitucional representa, em si mesma, uma mudança de paradigma. Há um intencional afastamento da idéia liberal de mera garantia formal de um direito, como se isto bastasse para apaziguar as aspirações da sociedade.

O novo momento constitucional vivido no mundo exige mais que a simples previsão de um direito fundamental. Ele vai além, quando estabelece instrumentos que permitam a concretização desses direitos.

É que, na busca da efetividade das garantias fundamentais há de se incentivar uma reflexão dialética entre o direito e outros campos, tais como ciência da administração, economia e urbanismo. Assim, assume relevo o ensinamento de Vanice Regina Lírio do Valle, no sentido de que o:

\begin{abstract}
“...reconhecimento como categoria também relevante no plano do direito de um instrumento que orienta a ação estatal - políticas públicas -é conquista cognitiva que, associada a um ambiente de Estado Democrático de Direito (...) [expressa] planejamento social a partir da execução dos projetos governamentais das sociedades contemporâneas." 15
\end{abstract}

Continua a autora:

“...o debate mais atual envolve não só a persecução de prestações concretas, a serem oferecidas por um Estado que se crê garantidor de um mínimo existencial; mas também o desenvolvimento por esse mesmo Estado, agora já em sua condição de articulador das forças sociais, de funções de planejamento e

\footnotetext{
${ }^{13}$ Idem, p.70.

${ }^{14}$ MOURA, Adriana Galvão. A dignidade da pessoa humana como fundamento da cidadania. In: Constituição e construção da cidadania. A. DINALLI, A, FERREIRA, Luiz Alexandre Cruz e TEOTÔNIO, Paulo José Freire (Org.). Leme: J. H. Mizuno, 2005, p. 34.

${ }^{15}$ Op.Cit., pp. 69- 70.
} 
fomento de um conjunto de outras atividades que, se não devem mais nele encontrar o executor exclusivo, ao mesmo tempo não podem dispensar sua presença como agente de coordenação."16

Esta coordenação ora é realizada diretamente pela administração pública, quando o Estado desempenha concomitantemente os papéis de prestador e executor dos serviços públicos ${ }^{17}$; ora de maneira indireta, por meio de fundações e autarquias e ainda em outros momentos, a prestação dos serviços públicos é realizada por particulares, sob a supervisão de entes da Administração pública. ${ }^{18}$ Aqui estão inseridas, as Agências Reguladoras, cujo papel principal consiste exatamente na supervisão e fiscalização dos serviços prestados pelos particulares, em colaboração com o Estado.

\title{
2. As agências reguladoras: conceito, origens e atribuições no direito brasileiro
}

As agências reguladoras surgem no âmbito do Estado brasileiro em decorrência do processo de desestatização ocorrido na década de 90 . O movimento teve como mote a busca da eficiência na prestação dos serviços públicos. Tanto que a emenda constitucional n. 19/1998 incluiu no artigo 37 da Constituição Federal, o princípio da eficiência.

Para a concretização deste comando, num país onde tradicionalmente os serviços públicos prestados diretamente pelo Estado não eram de boa qualidade, foi preciso idealizar um sistema em que, sem perder o poder de regulamentação, controle e fiscalização destes serviços, a sua prestação fosse transferida para a iniciativa privada.

Esta mudança acompanha a chamada impropriamente "privatização", numa postura neo-liberal experimentada mundialmente à época, no movimento de cognome "a terceira via", de matriz inglesa ${ }^{19}$.

Diógenes Gasparini lembra que:

\begin{abstract}
“Com a implementação da política que transfere para o setor particular a execução dos serviços públicos e reserva para a Administração Pública a regulamentação, o controle e a fiscalização da prestação desses serviços aos usuários e a ela própria, o Governo Federal, dito por ele mesmo, teve a necessidade de criar entidades para promover, com eficiência, essa regulamentação, controle e fiscalização, pois não dispunha de condições para en-
\end{abstract}

\footnotetext{
${ }^{16}$ Op. cit., p. 70.

${ }^{17}$ ARAÚJO, Edmir Netto de. Curso de Direito Administrativo. 4. ed. São Paulo: Saraiva, 2009, p. 150.

${ }^{18}$ Neste momento, mister se faz recordar a lição de Edmir Netto de Araújo no sentido de que é, "no mínimo, ingenuidade pretender separar as idéias de administração e de serviço público, pois se administração (genericamente) é a gestão dos negócios ou serviços de alguém, administração pública só pode significar, além da pessoa que a exercita (política, administrativa), o próprio desempenho do serviço público..." Op. cit., p. 128.

19 "A Terceira Via é a favor de crescimento, empreendorismo e criação de riquezas, mas é também a favor de maior justice social e acredita no Estado mais atuante para a consecução de tal finalidade" BBC News Disponível em: < http://news.bbc.co.uk/2/hi/uk_news/politics/458626.stm> Acesso em $31 / 10 / 2010$
} 
frentar a atuação dessas parcerias. Tais entidades, criadas com essa finalidade e poder, são as agências reguladoras." 20

Leila Cuéllar aponta a ausência de lei que defina o que seja uma agência reguladora no Brasil e a confusão quanto ao seu exato significado, decorrente das diversas acepções assumidas entre nós pelo vocábulo "agência". Contudo, a autora aponta que no nosso sistema, as agências reguladoras destinam-se "precipuamente a regular serviços públicos cuja execução passou a ser prestada por particulares" anotando ser "imperioso reiterar que a função desempenhada por agências reguladoras pode ter por objeto outras atividades econômicas" tal como ocorre nos Estados Unidos e na França. ${ }^{21}$

A administrativista, contudo, oferece um conceito de agência ao afirmar que:

\begin{abstract}
"Em suma: são pessoas jurídicas de Direito Público, com estrutura formal autárquica e competência para regulamentar, contratar, fiscalizar, aplicar sanções e atender aos reclamos dos usuários/consumidores de determinado serviço público ou atividade econômica." 22
\end{abstract}

Ary Casagrande Filho aponta os Estados Unidos da América como a fonte inspiradora do modelo de agências adotados no Brasil:

\begin{abstract}
"O modelo de agência reguladora aplicada no Brasil é baseado em certos aspectos, no modelo norte-americano. Preservam um certo grau de independência em relação ao Poder Executivo, como forma de torná-las isentas de pressões políticas, na medida em que contam com um certo grau de autonomia, inclusive financeira, pois são dotadas de verbas próprias. Suas decisões são tomadas por um órgão colegiado e seus diretores possuem mandato fixo." 23
\end{abstract}

Embora as agências reguladoras tenham florescido na década de 90, não se pode olvidar os exemplos Banco Central do Brasil - BACEN e do Conselho Administrativo de Defesa Econômica - $C A D E$, cuja origem remonta é bem anterior, e que, de certo modo, já exerciam atividades de natureza reguladora, também com a formatação de autarquias. ${ }^{24}$

\footnotetext{
${ }^{20}$ GASPARINI, Diógenes. Direito administrativo. 14. ed. rev. São Paulo: Saraiva, 2009, pp. 344-345.

${ }^{21}$ CUÉLLAR, Leila. As agências reguladoras e seu poder normativo. São Paulo: Dialética, 2001, p. 77. Há outros países que também adotam o sistema de agências reguladoras, tais como o Canadá, a Argentina, a Dinamarca, a Holanda, a Alemanha e a Suíça. (CASAGRANDE FILHO, Ary. Estado regulador e controle judicial. São Paulo: Quartier Latin, 2007, p.92).

${ }^{22}$ Idem, p. 81

${ }^{23}$ Op. cit.p. 93.

${ }^{24}$ Idem, ibidem. Interessante também, o apontamento de Maria Sylvia Zanella Di Pietro, lembrando trabalho de Manoel Gonçalves Ferreira Filho, sobre o papel das agências reguladoras e fiscalizadoras, em que indica a existência antiga em nosso ordenamento de autarquias econômicas que regulavam a produção e o comércio de determinados produtos, como o Comissariado de Alimentação Pública (1918), o Instituto de Defesa Permanente do Café (1923), o Instituto do Açúcar e do Álcool (1933), o Instituto Nacional do Sal (1940), além do Conselho Monetário Nacional e da Comissão de Valores
} 
Em relação às atribuições dessas autarquias especiais, Maria Sylvia Zanella Di Pietro leciona que:

\begin{abstract}
"As atribuições das agências reguladoras, no que diz respeito à concessão, permissão e autorização de serviço público resumem-se ou deveriam resumir-se às funções que o poder concedente exerce nesses tipos de contratos ou atos de delegação: regulamentar os serviços que constituem objeto da delegação, realizar o procedimento licitatório para escolha do concessionário, permissionário ou autorizatário, celebrar o contrato de concessão ou permissão ou praticar ato unilateral de outorga da autorização, definir o valor da tarifa e da sua revisão ou reajuste, controlar a execução dos serviços, aplicar sanções, encampar, decretar a caducidade, intervir, fazer a rescisão amigável, fazer a reversão de bens ao término da concessão, exercer o papel de ouvidor de denúncias e reclamações dos usuários, enfim exercer todas as prerrogativas que a lei outorga ao Poder Público na concessão, permissão ou autorização." 25
\end{abstract}

No sistema norte-americano o que entre nós denominamos de Direito Administrativo nada mais é do que o direito emanado das agências ou que cuidam das suas competências e atribuições.

É ainda de Maria Sylvia Zanella Di Pietro a afirmação de que:

"Enquanto no sistema europeu-continental, em que se inspirou o direito brasileiro, a Administração Pública tem uma organização complexa, que compreende uma série de órgãos que integram a Administração Direita e entidades que compõem a Administração Indireta, nos Estados Unidos toda a organização administrativa se resume em agências (vocábulo sinônimo de ente administrativo, em nosso direito), a tal ponto que se afirma que "o direito administrativo norte-americano é o direito das agências" (cf. Heloísa Carbonell et al., 1996:22)."26

Percebe-se que as agências reguladoras tiveram inspiração no direito comum e, por isto mesmo, podem apresentar alguma dificuldade de adaptação aos modelos oriundos do direito continental (civil law). ${ }^{27}$

Todavia, o grande desafio é a compatibilização das agências reguladoras e suas atribuições com os anseios dos administrados, o que só é atingido mediante prática de políticas públicas concretizantes.

\title{
3. Políticas públicas e o papel das agências reguladoras
}

As agências reguladoras desempenham relevante papel na economia e Mobiliários. (DI PIETRO, Maria Sylvia Zanella. Direito administrativo. 22. ed. São Paulo: Atlas, 2009, pp. 466-467).

${ }^{25}$ DI PIETRO, Maria Sylvia Zanella. Direito administrativo. 22. ed. São Paulo: Atlas, 2009, pp. 470-471.

${ }^{26}$ Idem, p. 462.

${ }^{27}$ DI PIETRO, Maria Sylvia Zanella. Limites da função reguladora das agências diante do princípio da legalidade. In: DI PIETRO, Maria Sylvia Zanella. Direito regulatório: temas polêmicos. Belo Horizonte: Fórum, 2003, pp. 49 e segs. 
podem influenciar na implementação e efetivação de políticas públicas, na medida em que estabelecem a regulação de monopólios, estabelecem regras relacionadas à concorrência no mercado e também realizam a chamada "regulação social", onde o objetivo primordial não é econômico, mas possibilitar a prestação de serviços de maneira universal e com respeito ao meio-ambiente ${ }^{28}$.

\begin{abstract}
"Apenas para que se vislumbre, $a b$ initio, a potencialidade de danos à concorrência e à sociedade advinda do exercício equivocado de competências normativas por parte das agências reguladoras, pense-se que essas têm por atribuição, dentre outros assuntos, dispor sobre condições de entrada e saída dos mercados, definição de tarifas, aspectos técnicos necessários para permitir o compartilhamento de redes e a interconexão, entre outros." 29
\end{abstract}

Portanto várias áreas da economia da vida em sociedade estão sujeitas à regulação das agências, de maneira que estas, por sua vez, podem auxiliar na concretização de políticas públicas no âmbito de suas atribuições. Apenas a título de exemplificação, podemos citar a telefonia e a energia elétrica como áreas intrinsecamente ligadas ao direito à moradia e ao trabalho.

Todavia é no campo da saúde complementar que se revela de maneira mais evidente a possibilidade de se aliar o trabalho realizado pelas agências reguladoras, com a promoção de políticas públicas. Afinal, em junho de 2010, 44 milhões de brasileiros eram beneficiários de plano de saúde complementar. ${ }^{30}$

Não se pode olvidar o comando previsto no artigo 170 da Constituição Federal: "A ordem econômica, fundada na valorização do trabalho humano e na livre iniciativa, tem por fim assegurar a todos existência digna..."

Esta finalidade, qual seja, a de assegurar a todos os brasileiros uma existência digna deve pautar toda atividade econômica desenvolvida pela iniciativa privada; cabendo às agencias reguladoras imporem regras, limites e, depois, fiscalizar a atuação das empresas privadas sob sua tutela, para que a determinação constitucional não se torne letra morta.

É que devemos atentar para o fato do mercado buscar apenas sua autosatisfação, almejando lucros cada vez maiores e deixar, para segundo plano, discussões relativas à concretização do preceito de universalização dos serviços públicos. ${ }^{31}$

\footnotetext{
${ }^{28}$ CUÉLLAR, Leila. As agências reguladoras e seu poder normativo. Dialética: São Paulo, 2001, p. 54.

${ }^{29}$ ARAGÃO, Alexandre Santos e SAMPAIO, Patrícia Regina Pinheiro. Omissão no exercício do poder normativo das agências e concorrência desleal. In: Aragão, Alexandre Santos de (Coord.). O poder normativo das agências reguladoras. Rio de Janeiro: Forense, 2006, p.547-548. Destaque no original.

${ }^{30}$ BRASIL, Agência Nacional de Saúde Complementar. Disponível em: http://www.ans.gov.br/ main.jsp?lumChannelId=8A9588D425FEC1700126057CFDC40CCD> Acesso em 30/10/2010.

${ }^{31}$ Oswaldo Aranha Bandeira de Melo em 1941 já discursava acerca do viés ganancioso do mercado eseusparticipantes: "...oserviçoexercidoporconcessão, em regra, temseu fim deturpadopeloconcessionário, oqueprocura satisfazerquasequeexclusivamenteassuasambiçóesgananciosas, em detrimentodobemestarcoletivo-razãodeser doserviço. Demais, a fiscalização do Poder Público, contraabusos dos concessionáriosémuito difíile dispendiosa, poisestesprocuram estabeleceromáximodetranstomosàaçãodoPoderPúblico,procurandoportodososmeios, fugiràsuainterferênciacontroladora" (Apud OLIVEIRA, José Carlos de. Concessões e Permissões de Serviços Públicos. Bauru: Edipro, 1997, p.134)
} 
Deste modo, mister se faz dotar os entes reguladores de "sensibilidade social", o que somente é possível mediante adoção de medidas hábeis a conferir maior concorrência entre os entes privados submetidos à regulação, bem como por meio de transparência de seus atos, o que se faz através do aprofundamento e melhoria de seus mecanismos de participação do usuário.

É neste contexto que se insere as agências reguladoras no âmbito da efetivação de políticas públicas. Afinal, são elas que fiscalizam a qualidade dos serviços prestados pela iniciativa privada no âmbito de suas atribuições, emitem normas e regras sobre a prestação de tais serviços, auxiliam no aprofundamento do princípio da livre-concorrência entre concessionários e podem, se devidamente alinhados com a idéia de efetivação de direitos fundamentais, ajudar na promoção de políticas públicas. Trata-se de atividade primordial, segundo reflexão apresentada por Eros Grau, primeiramente para proteger os próprios concessionários e, num segundo momento, o próprio consumidor:

\begin{abstract}
"O mercado é uma arena de luta, na qual cada concorrente configura - sartreanamente - para o outro, o inferno. A guerra, nos mercados, torna necessária a atuação do Estado para regular a concorrência, inicialmente protegendo os concorrentes. E essa proteção, com o tempo, passa a ampliar-se, de modo a se deslocar do concorrente para o consumidor. É inquestionável, na proteção dos consumidores, o desempenho, pelo Estado, da tradicional função que o move, de preservação dos mercados." ${ }^{32}$
\end{abstract}

Ocorre que, lamentavelmente, não se verifica isto. Jean Menezes de Aguiar apresenta crítica aguçada ao momento atual em que se apresenta o marco regulatório brasileiro, no qual se inclui o trabalho desempenhado pelas agências reguladoras:

\begin{abstract}
"A impressão que se tem é que o marco regulatório e sua ideologia foram entregues a hipertécnicos, preocupados com detalhes jurídicos e outros semelhantes que, de modo um tanto quanto purista, tiveram grande preocupação com tecnicalidades e procedimentalismos, mas não causaram - como aqui se defende deveriam ter causado e como se preocupou a Constituição da República de 1988 -, um choque de cidadania em termos de atividade estatal de regulação." ${ }^{33}$
\end{abstract}

Para que se possa causar verdadeiro "choque de cidadania" e efetivar políticas públicas que promovam os direitos fundamentais, as agências reguladoras devem se tomar permeáveis à participação popular, que deve ter acesso facilitado às agências, informação sobre a competência e poderes das agências e ter voz nos seus processos decisórios; de modo a se tornarem caixas de ressonância do clamor social daqueles

\footnotetext{
${ }^{32}$ GRAU, Eros R. Princípio da livre concorrência - função regulamentar e função normativa. Revista Trimestral de Direito Público. São Paulo: Malheiros, vol. 4, p. 125, 1993.

${ }^{33}$ AGUIAR, Jean Menezes de. Crítica ao marco regulatório do Brasil consumista: por uma regulação cidadã. In Zanotta, Pedro e Brancher, Paulo (Coord.). Desafios atuais da regulação econômica e concorrência. São Paulo: Atlas, 2010, p.164.
} 
que efetivamente utilizam os serviços prestados pelas empresas reguladas. Para o atingimento deste fim, propomos abaixo duas áreas cujo aperfeiçoamento jurídicoinstrumental permitirá maior aproximação das agências com a realidade fática e, conseqüentemente, auxiliará na adoção de políticas públicas.

\title{
4. Agestão democrática das agências na realização de políticas públicas: a participação popular e o papel do consumidor
}

Ao se estabelecer e aperfeiçoar instrumentos de participação social junto às agências reguladoras prestigia-se o envolvimento mais efetivo da população, que afinal, é formada por usuários ou usuários em potencial dos serviços regulados nas decisões, políticas, metas e trabalhos desenvolvidos pelas agências reguladoras.

Trata-se de medida imprescindível à legitimação do poder das agências reguladoras, uma vez que a ordem constitucional vigente decreta o povo brasileiro como fonte de todo o poder estatal. ${ }^{34}$

Os Estados Unidos, cujo modelo de agências reguladoras serviu de exemplo para o Brasil, estabelece no capítulo 4 do Administrative Procedure Act a maneira em que se dará a participação popular no processo decisório da agência:

\begin{abstract}
"que podem ser destacadas da seguinte forma: a publicação do projeto no Federal Register, a publicação de avisos prévios de que se está estudando a criação de normas, o recebimento das sugestões e críticas com devolução de resposta no preâmbulo da norma, a exigência de processo público com os registros dos atos que envolvem a elaboração da norma, audiências e a notificação específica de interessados ou grupos específicos." 35
\end{abstract}

Ainda que o ordenamento pátrio em matéria de agências reguladoras disponha de instrumentos capazes de legitimar seus atos por meio da participação popular ${ }^{36}$, tais como a audiência pública, a consulta pública, a existência de órgãos consultivos das agências, compostos por membros da sociedade civil e o direito de petição ${ }^{37}$; em realidade, há de se ressaltar a profunda diferença cultural existente entre a sociedade brasileira em relação a outras que preconizam a participação popular no processo de rule making das agências, em especial a sociedade norte-americana.

Enquanto nos Estados Unidos o fenômeno da sociedade organizada que busca a defesa de seus interesses remonta aos temos de sua colonização e independência, a sociedade brasileira não tem em seu caldo cultural, inclinação

\footnotetext{
${ }^{34}$ Parágrafo único do artigo $1^{\circ}$ da Constituição Federal: "Todo o poder emana do povo, que o exerce por meio de representantes eleitos ou diretamente, nos termos desta Constituição."

${ }^{35}$ FERREIRA, Cristiane Catarina de Oliveira. Participação social na elaboração de normas das agências reguladoras no Brasil e nos Estados Unidos da América do Norte. In: Di Pietro, Maria Sylvia Zanella (Org.). Direito Regulatório: temas polêmicos. Belo Horizonte: Fórum, 2003, p. 602.

${ }^{36}$ RHEIN SCHIRATO, Vítor. As agências reguladoras independentes e alguns elementos da Teoria Geral do Estado. In: Aragão, Alexandre Santos de; Marques Neto, Floriano de Azevedo (Coord.). Direito administrativo e seus novos paradigmas. Belo Horizonte: Fórum, 2008, p.523.

${ }^{37}$ FERREIRA, Cristiane Catarina de Oliveira. Participação social na elaboração de normas das
} 
para o mesmo grau de envolvimento:

\begin{abstract}
"Comparando-se a formação da sociedade norte-americana com a formação da sociedade brasileira, percebe-se um maior grau de disposição de participação na formação das decisões estatais naquela sociedade, o que torna mais evidente a legitimidade democrática dessas decisões." 38
\end{abstract}

Assim, questões relacionadas à concretização de políticas públicas, tais como o acesso aos meios de comunicação (telefonia), o desenvolvimento de infra-estrutura capaz de possibilitar o direito à habitação digna (acesso à energia elétrica) e a eficácia dos serviços de cobertura médica-odontológica privada (promoção e proteção da saúde) passam quase que despercebidos do cotidiano da sociedade brasileira, muitas vezes alheia tanto em relação à existência das agências reguladoras, quanto às atribuições e poderes destes entes.

Por esta razão, a legitimidade das decisões e ações tomadas pelas agências reguladoras poderá ser objeto de questionamento futuro, a menos que tal ato "seja realizado com a observância do devido processo administrativo e desde que tal processo não seja meramente uma formalidade, mas tenha efeitos concretos aferíveis." 39

Não obstante a existência de instrumentos de participação popular, acreditamos haver espaço para a adoção de outras medidas que a tornem mais clara e concreta no cotidiano das agências reguladoras. A exemplo do que já ocorre em determinados setores regulados nos Estados Unidos, poder-se-ia exigir uma consulta a comitê consultivo formado por especialistas, pesquisadores e membros da sociedade civil organizada, previamente à publicação inicial de projeto de norma regulamentar; exigir que a publicação inicial contenha o inteiro teor do projeto de norma e, também, obrigar a agência reguladora a notificar, previamente à emissão de norma, as entidades locais suscetíveis de serem afetadas pelo conteúdo da norma. ${ }^{40}$

Neste sentido, manifesta-se Floriano de Azevedo Marques Neto:

\begin{abstract}
"Parece muito importante o incremento nos mecanismos de permanente transparência e participação da sociedade na atividade das agências. Isto pode ser obtido tanto por mecanismos procedimentais (obrigar que todas as sessões ou reuniões deliberativas das agências sejam abertas ao público) como pela adoção de uma postura mais ativa das agências no sentido de incentivar a participação dos grupos interessados na regulação
\end{abstract}

agências reguladoras no Brasil e nos Estados Unidos da América do Norte. In: Di Pietro, Maria Sylvia Zanella (Org.). Direito Regulatório: temas polêmicos. Belo Horizonte: Fórum, 2003, p. 594-598.

${ }^{38}$ Op cit. p. 603.

${ }^{39}$ RHEIN SCHIRATO, Vítor. As agências reguladoras independentes e alguns elementos da Teoria Geral do Estado. In: Aragão, Alexandre Santos de; Marques Neto, Floriano de Azevedo (Coord.). Direito administrativo e seus novos paradigmas. Belo Horizonte: Fórum, 2008, p. 526.

${ }^{40}$ FERREIRA, Cristiane Catarina de Oliveira. Participação social na elaboração de normas das agências reguladoras no Brasil e nos Estados Unidos da América do Norte. In: Di Pietro, Maria Sylvia Zanella (Org.). Direito regulatório: temas polêmicos. Belo Horizonte: Fórum, 2003, p. 601. 
(e não apenas os operadores econômicos) nos processos de consulta e audiências públicas." 41

Outra sugestão apontada pelo mesmo autor é a descentralização territorial, o que aumentaria a capilaridade e a penetração das agências de modo a favorecer a percepção dos usuários da atividade realizada por este ente regulador, bem como tronar mais eficiente a fiscalização da atividade regularizada. ${ }^{42}$

Fato é que, a sociedade anseia pela concretização de políticas públicas por meio de melhores serviços públicos, ainda que desempenhados por entes privados, como se verifica pelo ranking de reclamações publicado pela Fundação de Proteção e Defesa do Consumidor-PROCON, do Estado de São Paulo, que indica três empresas sujeitas à fiscalização de agências das cinco mais reclamadas no ano de 2009.43

Em relação à problemática da qualidade dos serviços prestados pelos entes regulados, a própria lei de concessões, (Lei n. 8.987/95), em seu artigo 29, inciso XII estabelece a obrigação do poder concedente estimular a formação de associações de usuários visando a defesa de seus interesses em relação ao serviço público prestado. $E$ isto "deve ser feito pelas agências, a quem caberia incentivar, favorecer e, no limite, obrigar os agentes econômicos regulados a criar comitês de usuários ou grupos de representação para atuar como agentes de fiscalização, controle e informação para a própria agência."44

Também neste sentido leciona José Carlos de Oliveira:

\begin{abstract}
“...é necessária a instituição de um defensor dos usuários, que no exercício da representação, objetivando a proteção e defesa dos direitos dos representados, atuar de ofício, exercendo a tutela dos interesses homogêneos, toda vez que chegasse a seu conhecimento uma circunstância que lesione, restrinja ou vulnere, de forma atual ou potencial os direitos e interesses dos usuários. Esta prerrogativa não exclui as demais pessoas jurídicas públicas, privadas ou instituições que tenham interesse legítimo ou simplesmente legitimação ativa para atuarem na defesa destes direitos." 45
\end{abstract}

Caberia às agências, na medida em que editassem normas, buscar a eficiente universalização e melhoria dos serviços públicos. Neste sentido se manifesta Jean Menezes de Aguiar:

“O problema do marco regulatório no Brasil como aqui se discute, impõe-se pelo minimum de só se legitimar com um pano de fundo cujas pistas teóricas (...) [tenham] comprometimento visí-

${ }^{41}$ Op.cit. p.136.

${ }^{42}$ Op. cit. pp. 136-137

${ }^{43}$ Disponível em: <http://www.procon.sp.gov.br/pdf/

acs_release_ranking_e_graficos_cadastro_2009.pdf> Acesso em 31/10/2010. (Ainda não há dados referentes ao ano de 2010).

${ }^{44}$ MARQUESNETO, Floriano de Azevedo. Agênciasreguladorasindependentes: fundamentose seu regime

jurídico. 1.ed. 1.reimpressão. Belo Horizonte: Fórum, 2009, p.137

${ }^{45}$ Op.cit. pp. 140-141. 
vel para com a cidadania, a pobreza e a desigualdade brasileiras - isto sugere normas declaradamente preocupadas e efetivas com o integral cumprimento das cláusulas condicionais de contratos de concessão, por exemplo, identificadas como: regularidade, continuidade, eficiência, segurança, atualidade, generalidade e cortesia." ${ }^{46}$

É inegável que a maior participação popular no âmbito das agências reguladoras ensejaria na adoção de medidas que auxiliariam na implementação de políticas públicas que visassem maior universalização do acesso a bens e meios de comunicação, a infra-estrutura elétrica e ao bom atendimento clínico-ambulatorial realizado por entidades privadas conveniadas de planos de saúde complementar.

\begin{abstract}
"Na medida em que as agências logrem ser instrumentos para tornar mais efetiva e mais eficaz a intervenção estatal no domínio público, mormente quando essa intervenção se preste a imprimir pautas de políticas públicas no âmbito do setor regulado, temos conosco que elas apenas reforçam o caráter público (tanto no sentido republicano, quanto no sentido de permeável ao público, v.g., sociedade) da atuação estatal em face do domínio econômico." 47
\end{abstract}

Ante o exposto, verificas-se que a ampliação dos meios de atuação popular, bem como a adoção de mecanismos de participação efetiva dos consumidores nas agências reguladoras poderá auxiliar no processo de concretização de políticas públicas, representando novo fôlego ao atual processo de embate na relação governo, sociedade e agências.

\title{
5. Conclusão
}

A sociedade brasileira clama pela concretização de políticas públicas hábeis a lançar nosso país à condição inquestionável de país desenvolvido. Neste contexto, as agências reguladoras podem e devem auxiliar no atingimento desta meta por meio de uma atuação proativa no âmbito de suas competências.

Para tanto, necessário se faz diminuir o distanciamento entre a suas atuações atuais frente a realidade concreta apresentada no cotidiano da sociedade, dotando a população de meios de participação no processo decisório de regulação, ao passo em que se verifica também a efetiva instituição e fortalecimento de mecanismos de participação e defesa dos interesses consumeristas junto às agências.

Afinal, a autonomia da agência reguladora deve ser traduzida como meio de concretização das garantias fundamentais previstas no texto constitucional, efetivando-se as políticas públicas, o que somente é possível por meio de uma gestão mais democrática destes entes reguladores, de modo a permitir maior acesso e participação dos usuários.

\footnotetext{
${ }^{46}$ Op.cit., p.165

${ }^{47}$ MAROUESNETO, Floriano de Azevedo.Agênciasreguladorasindependentes: fundamentose seuregimejurídico. 1.ed. 1.reimpressão. Belo Horizonte: Fórum, 2009, p.95 (Destaque no original)
} 


\section{Referências bibliográficas}

AGUIAR, Jean Menezes de. Crítica ao marco regulatório do Brasil consumista: por uma regulação cidadã. In: Zanotta, Pedro e Brancher, Paulo (Coord.). Desafios atuais da regulação econômica e concorrência. São Paulo: Atlas, 2010.

ARAGÃO, Alexandre Santos e SAMPAIO, Patrícia Regina Pinheiro. Omissão no exercício do poder normativo das agências e concorrência desleal. In: Aragão, Alexandre Santos de (Coord.). O poder normativo das agências reguladoras. Rio de Janeiro: Forense, 2006.

ARAÚJO, Edmir Netto de. Curso de Direito Administrativo. 4. ed. São Paulo: Saraiva, 2009.

BRASIL, Agência Nacional de Saúde Complementar. Disponível em: http:// $\mathrm{w} \quad \mathrm{w} \quad \mathrm{w} \cdot \mathrm{a} \quad \mathrm{n} \quad \mathrm{s} \cdot \mathrm{g} \quad \mathrm{O} \quad \mathrm{v} \cdot \mathrm{b} \quad \mathrm{r} /$ main.jsp?lumChannelId=8A9588D425FEC1700126057CFDC40CCD $>$ Acesso em 30/ 10/2010.

CASAGRANDE FILHO, Ary. Estado regulador e controle judicial. São Paulo: Quartier Latin, 2007.

CUÉLLAR, Leila. As agências reguladoras e seu poder normativo. São Paulo: Dialética, 2001.

DI PIETRO, Maria Sylvia Zanella. Direito administrativo. 22. ed. São Paulo: Atlas, 2009.

FAGUNDES, Miguel Seabra. Controle dos atos administrativos pelo poder judiciário. 5. ed. Rio de Janeiro: Forense, 1979.

FERREIRA, Cristiane Catarina de Oliveira. Participação social na elaboração de normas das agências reguladoras no Brasil e nos Estados Unidos da América do Norte. In: Di Pietro, Maria Sylvia Zanella (Org.). Direito regulatório: temas polêmicos. Belo Horizonte: Fórum, 2003.

GANDINI, João A. D., BARIONE, Samantha F,, SOUZA, AndréEvangelista de. A efetivação dos direitos sociais à saúde e à moradia por meio da atividade conciliadora do poder judiciário. In: SANTOS, Lenir (Org.). Direito da saúde no Brasil. Campinas: Saberes, 2010.

GASPARINI, Diógenes. Direito administrativo. 14. ed. rev. São Paulo: Saraiva, 2009.

GRAU, Eros R. Princípio da livre concorrência - função regulamentar e função normativa. Revista Trimestral de Direito Público. São Paulo: Malheiros, vol. 4, 1993.

MACHADO NETO, Antônio Luís; Sociologia Jurídica. 6. ed.. São Paulo: Saraiva, 1987.

MARQUES NETO, Floriano de Azevedo. Agências reguladoras independentes: fundamentos e seu regime jurídico. 1.ed. 1.reimpressão. Belo Horizonte: Fórum, 2009.

MOURA, Adriana Galvão. A dignidade da pessoa humana como fundamento da cidadania. In: Constituição e construção da cidadania. A. DINALLI, A, FERREIRA, Luiz Alexandre Cruz e TEOTÔNIO, Paulo José Freire (Org.). Leme: J. H. Mizuno, 2005. 
OLIVEIRA, José Carlos de. Concessões e Permissões de Serviços Públicos. Bauru: Edipro, 1997.

RHEIN SCHIRATO, Vítor. As agências reguladoras independentes e alguns elementos da Teoria Geral do Estado. In: Aragão, Alexandre Santos de; Marques Neto, Floriano de Azevedo (Coord.). Direito administrativo e seus novos paradigmas. Belo Horizonte: Fórum, 2008.

SÃO PAULO, Fundação de proteção e defesa do consumidor - PROCON. Disponível em: $<\mathrm{h} \mathrm{t} \mathrm{t} \mathrm{p} \mathrm{:} \mathrm{/} \mathrm{/} \mathrm{w} \mathrm{w} \mathrm{w} \mathrm{.} \mathrm{p} \mathrm{r} \mathrm{o} \mathrm{c} \mathrm{o} \mathrm{n.} \mathrm{s} \mathrm{p.g} \mathrm{o} \mathrm{v} \mathrm{.} \mathrm{b} \mathrm{r} \mathrm{/} \mathrm{p} \mathrm{d} \mathrm{f} \mathrm{/}$ acs_release_ranking_e_graficos_cadastro_2009.pdf> Acesso em 31/10/2010.

SILVA, José Afonso da. Curso de Direito Constitucional Positivo. 9. ed. São Paulo: Malheiros, 1993.

VALLE, Vanice Regina Lírio do. Políticas públicas, direitos fundamentais e controle judicial. Belo Horizonte: Fórum, 2009. 
